Submitted $9^{\text {th }}$ August 2021

Accepted $26^{\text {th }}$ October 2021

\title{
MEASURING THE PASSION OF ENTREPRENEURSHIP SPIRIT ON STUDENTS IN INDUSTRIAL REVOLUTION ERA 4.0
}

\author{
LA Sylvia Chandradevi Widana ${ }^{1}$, Gede Sri Darma ${ }^{2}$ \\ Pendidikan Nasional University, Indonesia \\ lasylvia808@gmail.com ${ }^{1}$,sridarma@undiknas.ac.id ${ }^{2}$
}

\begin{abstract}
The aim of this research is to observe the effect of self-efficacy, earning expectation and endorser credibility on the entrepreneurial interest and entrepreneurial readiness. This research was done in Undiknas Graduate School. The research design was quantitative research, which was a causality relationship between the variables. The technique of collecting data was done using questionnaire to 102 students. The technique of analyzing data was done using structural equation modeling (SEM) with AMOS version 22 program. The result of this research showed self-efficacy had a positive and significant effect of 0,429 on the entrepreneurial interest and 0,416 on the entrepreneurial readiness. Earning expectation had a positive and significant effect of 0,454 on the entrepreneurial interest and 0,198 on the entrepreneurial readiness. Social media had a positive and significant effect of 0,363 on the entrepreneurial interest and 0,440 on the entrepreneurial readiness. Advertisement effectiveness had a positive and significant effect on the entrepreneurial readiness of 0,595.
\end{abstract}

Keywords: $\quad$ self-efficacy, earning expectation, social media, entrepreneurial interest, and entrepreneurial readiness

\section{INTRODUCTION}

The Fourth Industrial Revolution (Industry 4.0) is marked by the union of some technology, therefore we may see a new area which consists of three independent fields of knowledge, which are physics, digital and biology (Tjandrawinata, 2016). The new technology such as the internet, becomes a strategic point in the fourth industrial revolution process, especially in this current entrepreneurship (often called as an electronic-business) (Irsyada, etal., 2018). Therefore, the fourth industrial revolution brings an incorporation concept between the digital technology and the internet with the conventional industry which in the end, aims to increase the productivity, efficiency and customer service significantly (Prasetyo, 2017).

The economic field during this fourth industrial revolution currently is in the big change on the technology advances which may lead to the automation in almost 
every field. Among the challenges which are currently faced, the combination of technology and physical, digital word fundamentally changes the people. So far, this transformation has a positive impact.

The transformation has a positive impact, where the roles of business world and social organization are rated very strategic in strengthening the independence of national economy. Therefore, the economic growth encourages the development to be higher to attain the economic growth of 5\%. The increase of economic independence may encourage and strengthen the entrepreneurial orientation in order to grow better and attain the welfare of the citizen equally (Hamdan, 2018).

In this current digitalization era, the citizens who have high innovation and creativity will be able to channel their talent easier through digital entrepreneurship. With the great amount of citizens who do entrepreneurship, it may depress the number of unemployment. The problem of unemployment has been a big challenge for the government and citizen of Indonesia. Over the past few years, the number of unemployment has always increased (Hamdan, 2019).

The phenomenon of the lack of Indonesian teenager's interest and motivation in entrepreneurship becomes a serious thought for some sides, such as the government, educational field, industrial field, as well as the citizen. (Wedayanti \& Giantari, 2016) state that the data from Statistics Indonesia (Badan Pusat Statistik) shows that some of the unemployment in Indonesia are graduated from university. Therefore, the entrepreneurship learning program is one of the strategies which is important to do in order to change the tendency of someone as a jobseeker to become a job creator in the future. As the global business environment changes into digital era or fourth industrial revolution, the company and non-profit organization in Indonesia need to adapt and align their strategy with the human capital of the organization (Dora, 2019). According to Niode and Mopangga in (Irsyada et al., 2018), the weakness of mental and personality of young generation cause them to be not able to get achievement, get a courage to take risk, to be clever, to fight, to have an entrepreneurial self-interest and to be creative as well as innovative. These things have become a challenge for university as an education intuition.

University holds an important role in increasing the entrepreneurship spirit on the young generation. Education has a big impact in growing the interest of young generation to do entrepreneurship. As the result of research which was done by Pamungkas and Mustikawati (2017), they find education has a positive and significant impact on the entrepreneurial interest. Other than that, their result of research also finds that self-efficacy and earning expectation also have a positive and significant impact to the entrepreneurial interest.

The highness of motivation of a person will be able to grow the entrepreneurial interest. Aidha (2016) in her research finds that the high motivation to become entrepreneur on student may increase the student's entrepreneurial interest. It can be seen from the entrepreneurial planning which they will do after they graduated from university with their different interests too. Motivation from the ambition for freedom dimension is a factor which has the biggest impact on the entrepreneurial interest of student.

In this current digitalization era, other than self-efficacy and earning expectation factors, social media also holds an important role to increase the entrepreneurial interest. Rahayu and Laela (2018) in their research, find that social 
media users have a positive and significant impact on the student's entrepreneurial interest. But this result is not in accordance with the result of research which was done by Hartanti and Rohmad (2016) which stated that motivation had no significant impact on the entrepreneurial interest. This thing can explain that students actually have a quite high motivation, but they are less capable to accept failure. Whereas, an entrepreneur must has a risk-taking spirit (failure).

Either do Undiknas Graduate School, which has students with a quite well economic background. Other than quite well economy, most of the students of Undiknas Graduate School, especially the students of Master of Public Administration and Law Science study program, have already worked in government sector. The students with a quite well economic background tend to not want to fail in business, even though they have a high earning expectation and have a motivation to be entrepreneur.

\section{METHODOLOGY}

This research was done on Magister Program in Undiknas Denpasar. The research design was a quantitative research, which was a causality relationship between the variables. The technique of collecting data was done using questionnaire to 102 magister students. The technique of analyzing data was done using structural equation modeling (SEM) with AMOS version 22 program.

\section{RESULT AND DISCUSSION}

Since the empiric data in this research used questionnaire, therefore before doing the data analysis using SEM, the research instrument test would be done first. The research instrument test was done by using validity test and reliability test. After the data were valid and reliable, the next step was normality test, CFA and SEM using AMOS version 22 program. The result of the data analysis was showed in the picture below. 


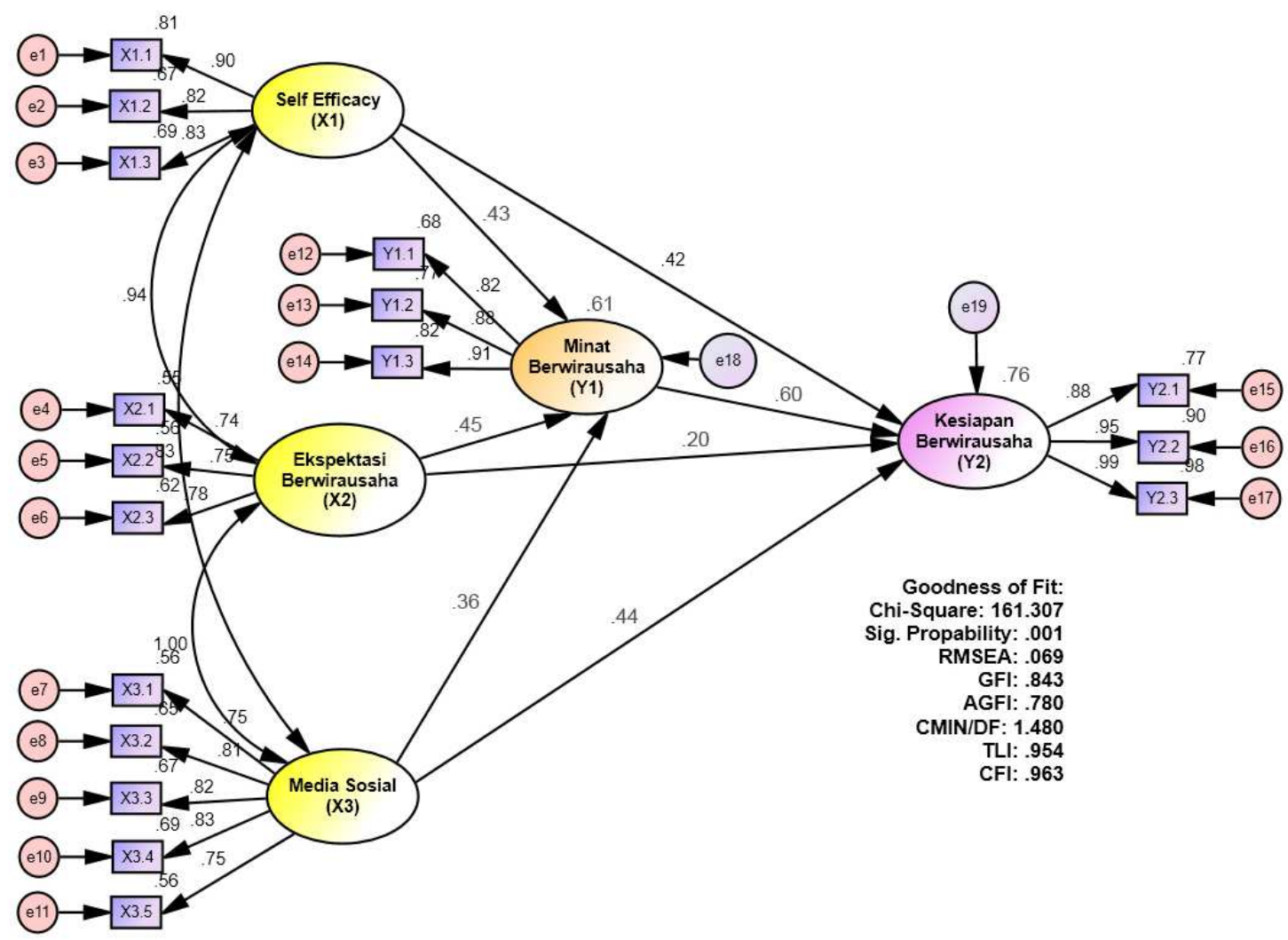

Picture 1: The Full Model Analysis Result of Causality Relationship Impact between Self-Efficacy, Earning Expectation, Social Media, Entrepreneurial Interest and Entrepreneurial Readiness

The testing model was conducted by using the regression weight for the selfefficacy variable, earning expectation variable, social media variable, entrepreneurial interest variable and entrepreneurial readiness variable through the output table as written in table 1 below.

Table 1: Structural Measurement Model of Unstandardized and Standardized Regression Weight

Unstandarized Standarized S.E. C.R. P Note Estimate Estimate

\begin{tabular}{|c|c|c|c|c|c|c|c|c|}
\hline Y1 & $<-$ & $\mathrm{X} 1$ & .456 & .429 & .163 & 2.790 & .005 & Significant \\
\hline Y1 & $<-$ & X3 & .387 & .363 & .200 & 3.433 & $* * *$ & Significant \\
\hline Y1 & $<-$ & $\mathrm{X} 2$ & .585 & .454 & .271 & 2.159 & .031 & Significant \\
\hline Y2 & $\begin{array}{l}<- \\
--\end{array}$ & X1 & .699 & .416 & .099 & 3.002 & $* * *$ & Significant \\
\hline Y2 & $\begin{array}{l}<- \\
--\end{array}$ & $\mathrm{X} 2$ & .205 & .198 & .168 & 2.023 & .041 & Significant \\
\hline
\end{tabular}




\begin{tabular}{|c|c|c|c|c|c|c|c|c|}
\hline Y2 & $\begin{array}{l}<- \\
--\end{array}$ & $\mathrm{X} 3$ & .345 & .440 & .122 & 2.367 & .018 & Significant \\
\hline $\mathrm{Y} 2$ & $\begin{array}{l}<- \\
--\end{array}$ & Y1 & .479 & .595 & .119 & 4.026 & $* * *$ & Significant \\
\hline
\end{tabular}

Source: research data, 2020

According to the analysis result above using path analysis, therefore, it can be explained that all variables have C.R. (critical ratio) value above 2,000 and sig value below 0,05 . This means that all exogenous variables have a significant direct impact on the exogenous variables.

Meanwhile, the testing of indirect impact of self-efficacy, earning expectation and social media to the entrepreneurial readiness through the entrepreneurial interest, is written in the table below.

Table 2. Indirect Impact

\begin{tabular}{lrrrrr}
\hline & $\begin{array}{c}\text { Social } \\
\text { Media }\end{array}$ & $\begin{array}{c}\text { Earning } \\
\text { Expectat } \\
\text { ion }\end{array}$ & $\begin{array}{c}\text { Self- } \\
\text { Efficacy }\end{array}$ & $\begin{array}{l}\text { Entrepreneur } \\
\text { ial Interest }\end{array}$ & $\begin{array}{c}\text { Entrepreneuri } \\
\text { al Readiness }\end{array}$ \\
\hline $\begin{array}{l}\text { Entrepreneuri } \\
\text { al Interest }\end{array}$ & .000 & .000 & .000 & .000 & .000 \\
$\begin{array}{l}\text { Entrepreneuri } \\
\text { al Readiness }\end{array}$ & .216 & .271 & .255 & .000 & .000 \\
\hline
\end{tabular}

Source: research data, 2020

Table 2 above shows the indirect impact of social media on the entrepreneurial readiness through entrepreneurial interest is 0,216 . The indirect impact of earning expectation on entrepreneurial readiness through entrepreneurial interest is 0,271 . And, the indirect impact of self-efficacy on the entrepreneurial readiness through entrepreneurial interest is 0,255 .

\section{The Effect of Self Efficacy on Entrepreneurial Interest}

Based on the analysis result, it can be concluded that the direct effect of selfefficacy variable to entrepreneurial interest has a C.R. value of 2,790 $>2,000$ and probability $=0,005<0,05$. It means, the self-efficacy effect on the entrepreneurial interest was positive and significant. Therefore, it can be said that the higher selfefficacy, the higher also the entrepreneurial interest. This analysis result is consistent with the argument by Hendro (2018:225) which states that in choosing a profession, it certainly cannot be separated from self-efficacy factor. Self-efficacy is a confidence in self to be able to run and organize something in order to get a maximum result. The confidence in self will be very important when running a profession, since to become an entrepreneur, a confidence is needed in running and organizing the business. A person, who chooses to become an entrepreneur, must have a high self-efficacy in entrepreneurship. Therefore, self-efficacy or confidence in self will influence the entrepreneurial interest. (Pamungkas, 2017) in his research, finds that self-efficacy has a positive and significant impact to the entrepreneurial interest which is showed with the significant value which lower than level of significant which is 0,050 or $(0,000<0,050)$ and $t$ calculated value of 
11,678 is bigger than $t$ table of 1,656 . This shows that self-efficacy has a positive and significant effect on entrepreneurial interest. It means, the higher the selfefficacy, the higher also the entrepreneurial interest.

\section{The Effect of Earning Expectation on Entrepreneurial Interest}

Based on the result of research, it can be known that the direct effect of earning expectation value on entrepreneurial interest has a C.R. value of 2,159 > 2,000 and probability $=0,031<0,05$. This means, the effect of earning expectation on entrepreneurial interest was positive and significant. Therefore, it can be said that the higher the earning expectation, the higher also the entrepreneurial interest. This result is consistent with the argument by Hendro (2018:301) which states that in choosing a profession or job, the salary or earning factor becomes an important consideration. The salary or earning is used to fulfill the daily needs such as primary needs, secondary needs and tertiary needs. Therefore, a person will choose a profession with high salary or earning in order to fulfill his daily needs. Earning expectation is a wish of someone to receive exchange in the form of material which is produced from the work. As an entrepreneur, a person certainly wishes to get a higher earning. The entrepreneur's earning is unlimited, therefore it becomes one of the factors of someone to choose to become an entrepreneur. With the hope to get a high unlimited income, it will influence the entrepreneurial interest.

Besides, this result of research is consistent with the result of research which was conducted by (Pamungkas, 2017). In his research, he finds that partial test (statistic $t$ test) of earning expectation variable is attained a $t$ calculated value of 8,535 bigger than t table of 1,656. Meanwhile, the significant value of 0,000 is lower than 0,05 . This shows that the earning expectation has a positive and significant effect on entrepreneurial interest. It means, the higher the earning expectation, the higher also the entrepreneurial interest.

\section{The Effect of Social Media on the Entrepreneurial Interest}

Based on the result of research, it can be known that the direct effect of social media variable on entrepreneurial interest has a C.R. value of 3,433 $>2,000$ and probability $=* * *<0,05$. This means that the effect of social media on entrepreneurial interest was positive and significant. Therefore, it can be said that the higher the social media usage, the higher the entrepreneurial interest. This result of research is consistent with the research which was done by (Mulyandi \& Puspitasari, 2018). They find that social media has a quite strong and significant effect on the growth of entrepreneurial interest among young generation. As the implication, it is very important for university to consider again the curriculum, especially related to the entrepreneurship development. The existence of entrepreneurship subject, not only as an obligation without the effort of soul development in students, but also as a needs inside the students. Growing the entrepreneurship spirit in every student can be done by giving a better space to the practical activity. (Asmawan, 2017) through his research, states that by doing the practice of entrepreneurship, the students will have courage and confidence to start a business. Effectively, students show their happiness while doing a business and connotatively show their motivation to keep doing business. 


\section{The Effect of Self-Efficacy on Entrepreneurial Readiness}

Based on the research result, it can be known that the direct effect of selfefficacy variable on entrepreneurial readiness has C.R. value of 3,002 $>2,000$ and probability $=* * *<0,05$. This means, the effect of self-efficacy on entrepreneurial readiness was positive and significant. Therefore, it can be said that the higher the self-efficacy, the higher the entrepreneurial readiness. This result of research is consistent with the research which was conducted by (Irsyada et al., 2018). They find that self-efficacy is a confidence of an individual in the self-ability to organize and perform a task effectively and efficiently. Therefore, the individual can reach the aim where he feels confident to face any difficulty and able to predict how big the effort will be needed to reach the aim. Other explanation about self-efficacy states that it is a confidence of people in their ability to train some control measures of the function of their selves from the accidents in their environment. The selfconfidence holds an important role in growing someone's interest (Farida and Nurkhin, 2016). Self-efficacy is a self-perception about how good ourselves can function in a certain situation. Self-efficacy related to the confidence that ourselves have an ability to do wished action.

\section{The Effect of Earning Expectation on Entrepreneurial Readiness}

Based on the result of research, it can be known that the direct effect of earning expectation variable on entrepreneurial readiness has a C.R. value of 2,023 $>2,000$ and probability $=0,041<0,05$. This means the effect of earning expectation on entrepreneurial readiness was positive and significant. Therefore, it can be said that the higher the earning expectation, the higher the entrepreneurial readiness. This research is consistent with the argument by (Zimmerer, Thomas W., 2018), which state that earning expectation is a wish of someone to receive an exchange in a material form which is created by the effort that he had done. Furthermore, it is said that if someone become an entrepreneur, he will receive a fantastic earning. An aggressive entrepreneur has a high earning expectation of his business in order to fulfill his daily needs and to develop his business.

This research is also consistent with the result of research which was done by (Davinci \& Maryati, 2011), which the result shows that there is a positive and significant effect from earning expectation on entrepreneurial readiness. It shows that during this time, as an entrepreneur, there is a wish to get a high earning from the activity that they should do.

\section{The Effect of Social Media on Entrepreneurial Readiness}

Based on the result of research, it is known that the direct effect of social media variable on the entrepreneurial readiness has a C.R. value of 2,367 $>2,000$ and probability $=0,018<0,05$. The C.R. value $=2,367>2,000$ and probability $=$ $0,018<0,05$. This means, the effect of social media on the entrepreneurial readiness was positive and significant. Therefore, it can be said that the higher the social media usage, the higher the entrepreneurial readiness. This research is consistent with the argument from (Keller, 2012). He says that social media is a tool for the consumer to share information, text, picture, audio and video to others or company and vice versa. The role of social media has been more recognized in encouraging the business performance. Social media has make it possible for the small business 
to change their way of communicating with the customer, marketing the product and service and also interacting with customer with the purpose to build a good relationship.

Other than that, this result of research is consistent with the research which was done by (Rahayu \& Laela, 2018) which show the significant effect of social media usage variable on the entrepreneurship of STIE IPWI Jakarta students. It is proven with the sig value result of $0.014>0.05$ which means Ho is rejected and $\mathrm{Ha}$ is received. The higher the social media usage, the higher the entrepreneurial readiness of the students too. Otherwise, the lower the social media usage, the lower also the entrepreneurial readiness of the students. This happens since social media has a communication role. According to (Morrisan, 2017), social media is an effort to make all marketing and promoting activities creating an image which is consistent for the students. On the other hand, according to (Setiadi in Nugroho, 2013), on the basic level, communication can give information and make the potential consumer realizes the product which is being promoted. Communication can try to persuade the current consumer and the potential consumer to have a desire into the exchange relationship.

\section{The Effect of Entrepreneurial Interest on Entrepreneurial Readiness}

Based on the result of research it can be known that the direct effect of entrepreneurial interest variable on entrepreneurial readiness has a C.R. value of $4,026>2,000$ and probability $=* * *<0,05$. This means, the effect of entrepreneurial interest on entrepreneurial readiness was positive and significant. Therefore, it can be said that the higher the entrepreneurial interest, the higher the entrepreneurial readiness. This result of research is based on the entrepreneurial interest theory which is assumed that, the higher the entrepreneurial interest of student, the higher their entrepreneurial readiness. Even though, similar with the statement of the assumption, the entrepreneurial interest of student still needs to be increase. Therefore, their entrepreneurial readiness will grow and develop better. The result of research is also supported by a previous research which was conducted by (Syaifullah, 2016) which states that the entrepreneurial interest consists of two which are spirit or internal, where the interest gives feeling and assumption that the individual is in a very great condition. The other is physical or external, which is a person's nature of belief of everything on himself that relates with the physical being.

The entrepreneurial interest that is carried by the students, gives them positive contribution to their entrepreneurial readiness. Besides that theory, this research is also consistent with the previous research which was done by (Bustan, 2014). He shows the positive relationship between the student's entrepreneurial interest and their entrepreneurial readiness. The increasing of student's entrepreneurial interest gives courage on the development of entrepreneurial readiness. The entrepreneurial readiness will develop better along with the increase of student's entrepreneurial interest. 


\section{CONCLUSION}

The result of the research showed that self-efficacy had a positive and significant effect on entrepreneurial interest. This means, the higher the selfefficacy, the higher also the entrepreneurial interest. Earning expectation had a positive and significant effect on entrepreneurial interest. This means, the higher the earning expectation, the higher also the entrepreneurial interest. Social media had a positive and significant effect on entrepreneurial interest. This means, the higher the social media usage, the higher also the entrepreneurial interest. Selfefficacy had a positive and significant effect on entrepreneurial readiness. This means, the higher the self-efficacy, the higher also the entrepreneurial readiness. Earning expectation had a positive and significant effect on entrepreneurial readiness. This means, the higher the earning expectation, the higher also the entrepreneurial readiness. Social media had a positive and significant effect on entrepreneurial readiness. This means, the higher the social media usage, the higher also the entrepreneurial readiness. Entrepreneurial interest had a positive and significant effect on entrepreneurial readiness. This means, the higher the entrepreneurial interest, the higher also the entrepreneurial readiness.

\section{REFERENCES}

Agung Widayoko. (2013). Pengaruh Efikasi Diri, Norma Obyektif, Sikap Berprilaku, dan Pendidikan Kewirausahaan Terhadap Intensi Berwirausaha Mahasiswa. E-Jurnal. Universitas Tri Sakti. Jakarta

Anugratami, F., Christin, M., \& Primadani, B. (2015). Pengaruh Penggunaan Media Sosial Twitter Terhadap Motivasi Followers Pada Akun@Merryriana. Human Ecology: A Theoretical Essay, 2(2), 2259. https://doi.org/10.5281/zenodo.1000462.RES

Asmawan, C. (2017). Dampak Mata Kuliah Praktek Kewirausahaan Terhadap Motivasi Mahasiswa Pendidikan Akutansi Untuk Berwirausaha. Makalah Dipersentasikan Dalam Seminar Nasional Pendidikan 2017.

Astiti, A. F., \& Margunani. (2014). Peran Motivasi Dalam Memediasi Pengaruh Pendidikan Kewirausahaan, Dan Lingkungan Terhadap Kesiapan Berwirausaha Mahasiswa. Economic Education Analysis Journal, 2(3), 4762. Retrieved from http://journal.unnes.ac.id/sju/index.php/eeaj

Budiwibowo, S. (2016). Hubungan Minat Belajar Siswa Dengan Hasil Belajar Ips Di Smp Negeri 14 Kota Madiun. Gulawentah:Jurnal Studi Sosial, 1(1), 60. https://doi.org/10.25273/gulawentah.v1i1.66

Davinci, abang asriyadi, \& Maryati, T. (2011). kesiapan berwirausaha mahasiswa tekik mesin universitas mehammadyah yogyakarta ditinjau dari pengetahuan kewirausahaan, dukungan keluarga, soft skill, dan prestasi belajar. JBTI, 66, 37-39.

Dewi K, P., Faslah, R., \& Budiarsih, L. (2017). the Effect of Learning Readiness 
and Learning Motivation on Learning Outcomes in the Subject Financial Administration At Smkn 62 Jakarta. Econosains Jurnal Online Ekonomi Dan Pendidikan, 15(1), 109-124. https://doi.org/10.21009/econosains.0151.07

Dora, Y. M. (2019). Minat, Jiwa Kewirausahaan Dan Pengetahuan Untuk Kesiapan Berwirausaha. Jurnal Muara Ilmu Ekonomi Dan Bisnis, 3(1), 92. https://doi.org/10.24912/jmieb.v3i1.3535

Dusak, I., \& Sudiksa, I. (2016). Pengaruh Pendidikan Kewirausahaan, Parental, Dan Locus of Control Terhadap Niat Berwirausaha Mahasiswa. E-Jurnal Manajemen Universitas Udayana, 5(8), 5184-5214.

Efendi, M., \& Yudhati, M. (2017). pengaruh ekspektasi laba terhadap minat berwirausaha. Jurnal AKP, 7(2), 1-7. Retrieved from http://www.albayan.ae

Greogory J. Feist. (2017). Teori Kepribadian. Jakarta: Salemba Humanika.

Hamdan, H. (2018). Industri 4.0: Pengaruh Revolusi Industri Pada Kewirausahaan Demi Kemandirian Ekonomi. Jurnal Nusantara Aplikasi Manajemen Bisnis, 3(2), 1. https://doi.org/10.29407/nusamba.v3i2.12142

Hamdan, H. (2019). Model Pengembangan Kreativitas dan Inovasi dalam Membentuk Entrepreneur di Era Ekonomi Digital. Jurnal Manajemen Dan Kewirausahaan, 7(1), 59-68. https://doi.org/10.26905/jmdk.v7i1.2548

Hendro. (2018). Dasar-dasar Kewirausahaan. Jakarta. Erlangga

Hidayat Dede Rahmat. (2017). Psikologi Kepribadian Dalam Konseling. Jakarta: Indeks

Irsyada, R., Dardiri, A., \& Sugandi, R. M. (2018). Kontribusi Minat Berwirausaha dan Self Efficacy terhadap Kesiapan Berwirausaha di Era Revolusi Industri 4 . 0 Mahasiswa Teknik Informatika se-Malang. Jurnal Pendidikan: Teori, Penelitian, Dan Pengembangan, 3(7), 945-954. Retrieved from http://journal.um.ac.id/index.php/jptpp/

Keller, K. dan. (2012). Manajemen Pemasaran. Jakarta.

Laura. (2016). Psikologi Umum. Jakarta : Salemba Humanika.

Morrisan. (2017). Periklanan : Komunikasi Pemasaran Terpadu. Jakarta.

Mulyandi, R., \& Puspitasari, veny anindya. (2018). Industri Kreatif, Media Sosial, Dan Minat Berwirausaha: Sinergi Menuju Pembangunan Berkelanjutan. (September), 5-6.

Nugroho J. (2013), Perilaku Konsumen. Kencana. Jakarta

Ormrod Jeanne Ellis. (2018). Psikologi Pendidikan (membantu siswa tumbuh dan berkembang jilid 2). Jakarta. Erlangga

Pamungkas, A. P., \& Mustikawati, R. I. (n.d.). Pengaruh Self Efficacy, Pendidikan Kewirausahaan Dan Ekspektasi Pendapatan Terhadap Minat Berwirausaha Mahasiswa Program Studi Akuntansi The Influence Of Self Efficacy, Entrepreneurship Education, And Earning Expectation Towards 
The Studentsinterest Of. (1), 1-13.

Prasetyo, H., \& Sutopo, W. (2017). Perkembangan Keilmuan Teknik Industri Menuju Era. Seminar Dan Konferensi Nasional IDEC 2017, 488-496.

Rahayu, E. S., \& Laela, S. (2018). Pengaruh Minat Berwirausaha Dan Penggunaan Sosial Media Terhadap Kewirausahaan Mahasiswa. Jurnal Pengembangan Wiraswasta, 20(3), 203. https://doi.org/10.33370/jpw.v20i3.246

Ridlwan, B., Fauzi, M., \& Said, A. (2012). Kewirausahaan (Entrepereneurship) Dalam Persepektif Qur'an dan Hadist. 153-157.

Saiman, L. (2017). Kewirausahaan. Teori, Praktik, dan Kasus-kasus. Jakarta.

Setiawan Deden. (2016). Pengaruh Ekspektasi Pendapatan, Lingkungan Keluarga Dan Pendidikan Kewirausahaan Terhadap Minat Berwirausaha (Studi Kasus Mahasiswa Akutansi Universitas Negeri Yogyakarta). E-Jurnal. UNY. Yogyakarta

Sintya, ni made. (2019). Jurnal Sains, Akuntansi dan Manajemen (Vol. 1, No. 1: Januari, 2019) Pengaruh Motivasi, Efikasi Diri, Ekspektasi Pendapatan, Lingkungan Keluarga, Dan Pendidikan Kewirausahaan Terhadap Minat Berwirausaha Mahasiswa Jurusan Akuntansi Di Universitas Mahasaras. 1(1), 337-380.

Slameto. (2016). Belajar dan Faktor-Faktor yang Mempengaruhinya. Jakarta.

Sugiyono. (2013). Metode Penelitian Pendidikan. Bandung.

Supeni, R. E., \& Efendi, M. (2017). Minat Mahasiswa Dalam Berwirausaha Pada Perguruan Tinggi Swasta Di Kabupaten Jember. Prosiding Seminar Nasional Dan Call For Paper Ekonomi Dan Bisnis, 2017, 27-28.

Syaifudin, A. (2014). The Influence Of Personality, Family Environment, And Entrepreneurship Education Towards Interest Entrepreneurship Oleh Wakil Ketua Umum Kadin Bidang. (3), 2.

Tjandrawinata, R. R. (2016). Raymond R. Tjandrawinata - 2017 - Industri 4.0 Revolusi Industri 4.0 Revolusi Industri Abad Ini Dan Pengaruhnya Pada Bidang Kesehatan Dan Bioteknologi. 29(1), 31-39.

Wedayanti, N., \& Giantari, I. (2016). Peran Pendidikan Kewirausahaan Dalam Memediasi Pengaruh Norma Subyektif Terhadap Niat Berwirausaha. EJurnal Manajemen Universitas Udayana, 5(1), 533-560.

Zimmerer, Thomas W., D. (2018). Kewirausahaan dan Manajemen Usaha Kecil. Jakarta. 